\title{
ОБУЧЕНИЕ КАК РЕЗУЛЬТАТ УСПЕШНОГО ВОСПИТАНИЯ
}

\author{
Дарханова Ризиг-ма Ефимовна \\ преподаватель истории \\ методист ГАУ ИО « Центр развития \\ дополнительного образования детей»
}

Аннотация: На сегодняшний день в образовательном процессе на основании распоряжения Правительства Российской Федерации от 12.11.2020 $\mathrm{N}$ 2945-P разработаны стратегии развития воспитания в Российской Федерации на период до 2025 года». В силу расставленных приоритетов в образовательном процессе считаем необходимым использовать педагогический опыт учителей. В данной статье мы продемонстрируем педагогический опыт, который представлен в трех разделах. В первом разделе мы уделили внимание методике воспитания в формировании классного коллектива, где на примере одного класса поэтапно рассмотрен как шел этот процесс на протяжении нескольких лет. Во втором разделе отражены результаты в воспитании, и как они повлияли на процесс обучения учащихся. Дается анализ процессу формирования личности через воспитание ответственности, через доверие, через предоставления права выбора. В третьем разделе мы выступили с предложением, чтобы воспитание охватывало весь образовательный процесс, не только внеурочное время, но и урочное. Предлагаем на каждом учебном занятии ввести обязательный элемент из истории края, региона.

Ключевые слова: Обучение, воспитание, образовательный процесс.

\section{EDUCATION AS A RESULT OF SUCCESSFUL UPBRINGING}

\section{Darkhanova Rizig-ma Efimovna}

Abstract: To date, in the educational process, on the basis of the order of the Government of the Russian Federation of 12.11.2020 N 2945-R, strategies for the development of education in the Russian Federation for the period up to 2025 have been developed. "Due to the priorities set in the educational process, we consider it 
necessary to use the pedagogical experience of teachers. In this article, we will demonstrate the teaching experience that is presented in three sections. In the first section, we paid attention to the methods of upbringing in the formation of a class collective, where, using the example of one class, we step by step considered how this process went over several years. The second section reflects the results in education, and how they influenced the learning process of students. The analysis is given of the process of personality formation through the education of responsibility, through trust, through the granting of the right to choose. In the third section, we made a proposal that upbringing should cover the entire educational process, not only extracurricular time, but also lesson time. We propose to introduce an obligatory element from the history of the region, region at each lesson.

Key words: Teaching, upbringing, educational process.

\section{1. Методика воспитания в формировании классного коллектива}

- Просмотр и анализ документов учащихся.

В классе было 20 учеников: 8 девочек, 12 мальчиков. Ребята были разные по темпераменту, по интеллекту, по интересам. Было необходимо из данной разношерстной кампании создать сплоченный коллектив. Изучив личные дела, познакомившись с достижениями и успехами каждого из ребят, мы провели анкетирование, ознакомились с психолого-педагогической диагностикой и для себя определили предпочтения каждого из них.

- Организация жизнедеятельности классного коллектива.

Был сформирован актив класса первоначально из числа желающих, путем открытого голосования. Обычно в школьной практике активы выбирались на год, их списки висели на уголках класса до конца учебного года. Мы же в своей практике применили ротацию должностей актива. Допустим у министра по культуре был свой заместитель, и в случае если министр не справлялся со своими обязанностями, то он был вынужден признать свои ошибки и уступить или заместителю (это опять решал сам коллектив), или избирали из числа достойных ребят, кто сумел проявить свои организаторские качества. Каждую неделю, по расписанию проходил классный час, на котором бурно обсуждались все успехи и неудачи в школьных делах. Ребятам очень понравился такой подход в выборе актива, и в возможности ротации . Идея была такова, независимо как учится ученик, он может стать или президентом класса, или министром в активе. По мере 
занятия должностей ребята невольно начинали осознавать необходимость в улучшении своих результатов в обучении, становились ответственными не только за себя, но и за результаты своего класса ( стыдно было перед классом президенту получать «2»). Таким образом, в учениках стало развиваться чувство ответственности.

- Работа с учащимися из « группы риска».

В процессе воспитания и формирования классного коллектива была выявлена « группа риска». Для того, чтобы оказать помощь ребятам, чтобы минимизировать риски в образовательном процессе мы тесно сотрудничали с психологом школы. Ознакомившись с результатами диагностических исследований, был определен план работы с ребятами из «группы риска». Были проведены беседы с каждым учащимся из этой группы. Родители были ознакомлены с результатами диагностики и планом работы с их детьми. Была заведена тетрадь для бесед, где фиксировался каждый случай. Причем, после обсуждения ребята расписывались в акте беседы, этим самым они подтверждали свою ответственность за содеянное. Главная задача классного руководителя состояла в том, чтобы создать условия для того, чтобы ребята имели поручения, а проявляясь в делах, у них не будет времени заниматься посторонними делами. Например, конкурс среди учащихся, посвященный 23 февраля. Выступление было организовано так, чтобы участвовал весь класс: мальчик и девочка читали стихи; вокальная группа на заднем плане сцены пела песни на военную тему; хореографическая группа выполняла танцевальные этюды. Таким образом, путем вовлечения всего класса в творческую деятельность росла ответственность за классный коллектив перед всей школой. Каждая грамота для моих ребят была заслуженной наградой за их собственные достижения. Так формировалось чувство взрослости и ответственности за коллектив.

- Сотрудничество с родителями.

Безусловно, в деле создания и воспитания классного коллектива большую помощь оказывают родители. Дружный родительский комитет поддерживал нас во всех моих начинаниях: будь то культурные выезды в театр, кинотеатр, экскурсии на предприятия или же ремонт кабинета. С пятого класса была введена традиция проводить родительские собрания с приглашением педагогов-предметников, психолога, социального педагога и заместителя директора по воспитательной работе. Очень продуктивно 
проводить такие собрания в присутствии не только отдельных учащихся, но и всего класса. В подростковом возрасте у учащихся начинает проявляться такое качество как двуличие: дома они одни, а в школе они другие. Совместные родительские собрания родителей, учащихся и педагогов помогают расставить все на свои места. Зачастую родители много нового узнавали на этих собраниях о своих детях. Взаимное стремление помочь нашим детям стать успешными, попробовать свои силы и знания в деле в конечном итоге дали свои плоды. Таким образом, достигалось всестороннее взаимодействие в работе по формированию классного коллектива.

- Итоги кропотливого труда.

Три года шло поступательно формирование классного коллектива. За эти годы ребята попробовали свои силы в разных областях ученической деятельности: учебной, воспитательной, творческой, исследовательской, трудовой. Теперь им можно было доверить ребятам подготовку любого мероприятия. Актив класса готовил план мероприятий класса. Инициативная группа готовила сценарий, а потом приглашали всех на совместное обсуждение и показ. Пришло время «собирать камни», то есть пожинать результаты многолетнего труда. Результат был на лицо - ребята стали самостоятельными, ответственными, ориентированными на успех и в учебе, и во вне учебной деятельности. Таким образом, поставленные цели в деле формирования классного коллектива были достигнуты, а это означало, что эти положительные результаты способствовали формированию наших учеников как личностей.

\section{2. Влияние процесса воспитания на результаты в обучении}

Начало нового учебного года-года выпускного. Традиционно, в первые недели учебы, после проведения вводных контрольных работ, происходит встреча и беседа с учителями- предметниками. Первой впечатление высказала учитель математики. Дословно она сказала так: « Я не знаю, что и как вы сделали со своими «гэшками»(9 «г»), но они теперь по математике решают и выполняют лучше, чем хваленный 9 «а». Действительно, перед нами стояли повзрослевшие, целеустремленные, ответственные ученики. Впереди был сложный не простой год - выпускные экзамены. Каждый из ребят осознавал, что пришла пора доказать на экзаменах насколько у них знания прочные и помогут получить аттестат об окончании основной школы. На первом родительском собрании родители сознались, что они больше, чем их дети 
переживают за результаты на экзаменах. И это было вполне понятно. На первом классном часе было проведено анкетирование по выбору экзаменов. Ответы были уверенными, четкими и обоснованными. На протяжении всего учебного года проводилась совместная работа с учителямипредметниками и психологом по преодолению психологических барьеров в подготовке к экзаменам. Два раза в месяц проводились родительские собрания, на которых выступали с текущими результатами контроля учителяпредметники. Прозрачность всех удач и промахов ребят в процессе подготовки к экзаменам способствовала тому, что ребята теперь сами были заинтересованы в улучшении своих результатов. Не было давления ни со стороны учителей, ни со стороны родителей. Беседы с родителями о правильной организации учебного процесса были правильно оценены и услышаны ими. Родители смогли дома создать комфортную среду для улучшения качества обучения, без постоянных наставлений удалось создать атмосферу взаимодоверия. Задача как классного руководителя теперь заключалась в корректировке действий в принятии правильных решений. Принцип доверия здесь сыграл самую важную роль. Беседы начинались так: «Ребята, вы уже взрослые и готовы самостоятельно принимать решения. Но если вы считаете себя таковыми, значит вы готовы нести ответственность не только за свои действия и поступки сейчас, но и за свое будущее. Будущее-это хорошее образование. Если вы сейчас упустите момент, то потом очень сложно будет догонять». Результатом наших совместных усилий стало то, что ребята из класса все успешно сдали экзамены, поступили в колледжы и техникумы на базе 9 класса. Качественные показатели в обучении (более $50 \%$ ), которые свидетельствовали о благотворном влиянии воспитания на процесс обучения, были подтверждены. Теперь уже не страшно было отпускать ребят в самостоятельное плавание, называемое «взрослая жизнь».

\section{3. Воспитание через обучение на предметных занятиях}

В этом разделе хотелось бы поговорить о необходимости включения элементов воспитания не только на уроках гуманитарного цикла (литературе, истории, обществознании), но и на всех учебных занятиях. Воспитание чувства гордости за малую родину через знание выдающихся личностей в разных областях. Например, на уроке математики, физики использовать краеведческий материал о заслуженных учителях - математиках нашего края. Эта информация займет буквально несколько минут, но вызовет большой 
интерес к своему краю. Точно по такому принципу можно использовать краеведческий материал на любом уроке. Урок физической культуры рассказать о наибольших достижениях спортсменов своего края. На уроках технологии показать и познакомить с теми народными промыслами, известными в крае. На занятиях по предмету МХК уделить внимание развитию культуры коренных народов. На уроках биологии и географии рассказать об исследователях края. В каждом образовательном учреждении необходимо скоординировать действия по достижению воспитательных целей.

В завершении нашей статьи хочется обратиться к высказыванию классика советской педагогики - Макаренко А.С., который твердо был убежден в том, что в образовательном процессе в первую очередь идет процесс воспитания, а затем обучение. Нельзя не согласиться с мнением классика педагогики. Действительно, только тот педагог может считать себя настоящим педагогом, который проживает вместе со своими учениками весь период становления их личностями. 